\title{
Democracy and the Multitude Spinoza against Negri
}

Sandra Field

\begin{abstract}
Negri celebrates a conception of democracy in which the concrete powers of individual humans are not alienated away, but rather are added together: this is a democracy of the multitude. But how can the multitude act without alienating anyone's power? To answer this difficulty, Negri explicitly appeals to Spinoza. Nonetheless, in this paper, I argue that Spinoza's philosophy does not support Negri's project. I argue that the Spinozist multitude avoids internal hierarchy through the mediation of political institutions and not in spite of them; nor do these institutions merely emanate from the multitude as it is, but rather they structure, restrain and channel its passions. In particular, the required institutions are not those of a simple direct democracy. There may be other non-Spinozist arguments on which Negri can ground his theory, but he cannot legitimately defend his conception of the democratic multitude by appeal to Spinoza.
\end{abstract}

Keywords: democratic institutions, multitude, Negri, power, radical democracy, Spinoza

In recent years, Antonio Negri's radical democratic theory (Negri 1999; Hardt and Negri 2000, 2004) has drawn considerable attention. His theory revolves around a distinction between constituent power and constituted power. Constituent power is the direct power of the people prior to any representation: in Negri's terms, it is the power of the multitude. By contrast, constituted power is the power of institutions (Negri 1999: 1-35). Negri's radicalism lies in conceiving of true democracy as a democracy of the multitude. Any limitation, mediation or regularisation of the multitude (any taming of its constituent power into forms of constituted power) is viewed as a betrayal of the originary democratic authority of the people. Even if the multitude decides that rules and procedures are necessary to the administration of life in common, vigilance is required to keep such rules and procedures bound and subordinate to the multitude's constituent power (Negri 1999: 1-35, 303-35; Hardt and Negri 2000: 348-58; 2004: 361-4). Practically, democracy's exemplars are social and revolutionary movements in which humans spontaneously act together as non-hierarchical equals (Hardt and Negri 2004: 211-9). ${ }^{1}$ Negri claims the 
philosophical underpinnings of this theory are Spinozist. Constituent power is correlated with Spinoza's potentia; constituted power, with potestas; and the elusive concept of the multitude is a direct translation of Spinoza's multitudo (Negri 1991: passim but especially xvii-xix, 226-9; 1998; 1999: 2; 2004a; Hardt and Negri 2000: 344, 408).

Negri's radical democracy has been celebrated by some and criticised by others, (Laclau 2004; Passavant 2004; Shapiro 2004; Žižek 2005; Mouffe 2006: 107-15) but in either case, his recourse to Spinoza has not generally been questioned. ${ }^{2}$ The purpose of this paper is to place the relation to Spinoza under scrutiny. For at the most difficult and pivotal point in his theory explaining how a multitude can act without forsaking its nature as multitude Negri appeals to Spinoza for support, often adverting to his own monographs on Spinoza (Negri 1999: 24, 322-4; Hardt and Negri 2000: 344, 2004: 189 $90)$. In this paper, I argue that Spinoza's philosophy does not in fact support Negri's project. ${ }^{3}$ Whereas Negri understands the multitude as a domain of originary equality amongst humans, for Spinoza human equality is a fragile achievement. I argue that the Spinozist multitude achieves equality through political institutions and not in spite of them; nor do these institutions merely emanate from the multitude as it is, but rather they structure, restrain and channel its passions. In other words, the power of the multitude is inseparable from the institutional mediation that shapes it. Furthermore, I deny that the optimal expression of the power of the democratic multitude is achieved through a pure direct democracy.

This paper poses but does not take up an invitation to translate the seventeenth-century institutional details of Spinoza's democracy of the multitude to the contemporary world. Nonetheless, whatever the precise details of that translation, they will not coincide with Negri's radical democracy. The opening passages of the Political Treatise (Spinoza 2000; cited as TP) criticise philosophers for their utopianism, or, in other words, for 'conceiv[ing] men not as they are, but as they would like them to be' (TP 1.1). In spite of Negri's protestations that his own theory is not utopian (Negri 1999: 14; Hardt and Negri 2004: $\mathrm{xviii)}$ his romanticised notion of the multitude neither conceives of humans as they are, nor even as they can be once alienating political structures are removed, but rather as Negri would like them to be. There may be other nonSpinozist arguments on which Negri can ground his theory, but he cannot defend his conception of the democratic multitude by appeal to Spinoza.

\section{The Problem of the Democratic Multitude}

The core difficulty for Negri's proposed democracy of the multitude is how to conceive the capacity of the multitude to exercise political agency without surrendering its character as a multitude (Hardt and Negri 2000: 394-400; 2004: 100, 350). Negri recognises the seriousness of this difficulty, and uses 
an exegesis of Spinoza both to characterise the problem (this section) and to pose a solution (the following section).

In Latin, there are two different words standardly translated into English as power: potentia and potestas. The distinction between the two generally corresponds to a distinction between power as a concrete capacity, and power as a juridical entitlement or authority. The theory of politics in the social contract tradition centres on the latter term, potestas. It imagines individuals becoming political subjects by transferring to the sovereign an authority to use their capacities (potentiae). This authority is the sovereign's power (potestas); it is a constituted power arising out of and superseding the constituent power of the masses. Hobbes is the exemplar of this tradition; in correlating right with power (potestas), he attributes to the sovereign in any political order the absolute authority to represent the people; the people must simply obey (Negri 1991: 112-14, 140; 1998: 222-3; Hobbes 1994: xvii.13). Negri situates Spinoza in the alternative and opposed tradition of 'republican materialism'. Republican materialists favour a political realism concerned with the concrete determination of the social domain; that is, with potentia. Political power always remains concretely in the bodies of the human individuals who make up the multitude. Consequently, any political order that attempts to obfuscate the popular ground of political power, for instance by attributing authority to rule to a monarchy or an aristocracy, finds itself inherently weaker and more fragile than democracy (Negri 1991: 195; 1998: 226-7; 2004a: 103, 110-11). Spinoza's own idea of imperium absolutum (absolute rule or sovereignty) has nothing to do with a juridically transcendent sovereign; because power is conceived concretely, absolute power can only be achieved in democracy (democraticum imperium). 'For if there is such a thing as absolute sovereignty [imperium absolutum], it is really that which is held by the people as a whole [integra multitudo]' (TP 8.3; cited at Negri 1998: 228). Thus, when Spinoza infamously asserts that right is coextensive with power (potentia), this does not amount to the unsavoury dictum that might makes right, nor to some perverse redefinition of oppression as freedom as it appeared in Hobbes. Rather, it amounts to a conception of freedom and right which refuses juridical mystification (Negri 1991: 192-3; 1998: 225-6).

Negri recognises that constituted power can take on democratic forms. Indeed, despite a predilection for monarchy, Hobbes grants that a democratic assembly can be the absolute representative of the will of the people just as a monarch can (1994: xix.1). At the same time, Hobbes insists that the multitude does not have a will nor a capacity for agency; the disordered crowd needs to be represented in order to act. He entirely rejects the idea that there could be a democracy of the multitude (1994: xvi.13, xvii.4). Against the Hobbesian refusal, Negri claims that Spinoza offers a democracy which remains of the multitude, and avoids any alienation into constituted powers (1998: 225-6).

To understand what this might mean, it is first necessary to understand more clearly the nature of the multitude. Negri appeals to the TP's two differ- 
ent accounts of how people combine together in groups, which he casts as a distinction between potestas and potentia (1991: 190-7). On the one hand, a group can be vertically constituted, as when one person has another in their power (sub potestate habere) (TP 2.9-11). This occurs on a grand scale in the case of aristocracies and monarchies; it constitutes a relation of command and submission. On the other hand, the simplest type of combination occurs horizontally, when two people join their forces together, thereby achieving a greater power (potentia) than they possessed individually, and correspondingly a greater right (TP 2.13; Negri 1998: 225; 2004b: 16). For Negri, this is the foundational metaphysical principle of the multitude. Negri characterises individual humans as 'free singularities'; they each have their own concrete material existence, constituted from their own actual desires and capacities. In Negri's view, the multitude adds these singularities (these actual bodies of citizens or subjects) together as equals on a flat social plane (1998: 225, 228; 1999: 330-2). The multitude is the complex materiality of the populace in which '[e]ach singularity is a foundation' (Negri 1998: 235).

In order for a multitude to act, its power taken as a whole will have a vertical relation to its individual members. In principle this is acceptable and does not constitute an alienation of power, so long as this command of the whole is flattened onto the concrete multitude: this is the fundamental idea of Negri's democracy of the multitude (Negri 1998: 230; 2004b: 17).

[B]y traversing the multitudo of subjects, democracy becomes absoluteness, for it puts all social powers into motion from below, and from the equality of a natural condition. Democracy as an omnino absoluta form of government means, then, that there is no alienation of power - neither in relation to its exercise, nor in relation to its formation or the specificity of the executive action, that is, the specificity of the figure of magistracy. (Negri 1998: 228)

However, this democracy of the multitude faces a difficulty. How can the multitude act and exercise power without ceasing to be a multitude? The problem arises because the multitude lacks real unity: it remains physically and objectively 'an elusive totality of singularities' (Negri 1998: 231). Any collection of individuals will have desires and intentions pulling in different directions. If such a group nonetheless acts, its power can no longer be 'of' the whole group in a material sense, because it has not incorporated the powers of all its individual members. It is this problem that gives rise to representationalist accounts of a group's will: for if the multitude can be said to be transcended by a single will of the people which absorbs and eliminates the singularity of its component parts, this explains how an action can be attributed to a group as a whole despite internal disagreement. It is not only Hobbes who takes this view: when Hegel equates absolute sovereignty with freedom, in the same gesture he dismisses the multitude as a mere heap of people (Negri 1998: 229). For Negri, by contrast, any popular rule which relegates the multitude in this way thwarts freedom and is not truly absolute (1991: 190-1). Negri's 
gloomy interim conclusion is that the tension between democracy and the multitude is unsolvable. 'Every value, every choice, every political act must be deployed on the basis of the incomplete relationship between the absoluteness of power and the multiplicity of propositions, needs, and experiences' (1998: 232).

Negri concedes that Spinoza's earlier text, the Theological-political Treatise, (Spinoza 2001; cited as TTP) poses what may appear to be a solution: the principled toleration of singularities.

The nonsolution of the problem of the political subject becomes the foundation of tolerance, of respect for consciences, of freedom to philosophize. The multitudo, in its paradoxical nature, is the foundation of democracy insofar as it allows each individual to introduce into society his own values of freedom. (Negri 1998: 235)

Nonetheless, this is not truly a solution. For first, not all politics and life in society with others can be privatised as tolerance. There is an irreducible need to act on common matters, and this demands a unity that it is not clear the multitude possesses. It is possible that individuals all desire different things, and do not have enough common feeling to come to agreement (Negri 1998: 235). And second, even achieving unity as a society of extensive toleration may be elusive; this would require the multitude already to be rational enough to desire to tolerate differences. For several common passions work against the willingness to tolerate diversity (Spinoza 1994: E IIIP31C, IIIP31S, IVP34S, IVP37S1; cited as E).

For Negri, Spinoza's later TP provides a more profound response, in the form of an advocacy of radical democracy which does not rest content with the liberal privatisation of differences (1991: 118-19, 186). The unification of the populace into a mass democratic subject capable of action must not be achieved by normative or juridical fiat; for this would be to outstrip the real concrete nature of the powers of individuals. But unification can be achieved if there is a real concrete change to those powers so that in fact they converge: 'a convergence of cupiditates [desires], to the extent that under the aegis of reason, the latter are materially displaced from the individual good to the collective good' (Negri 1998: 237). The name for this required orientation to the common good is pietas: piety or, better, morality (as in the Curley translation). Spinoza defines pietas as ' $\mathrm{t}]$ he desire to do good generated in us by our living according to the guidance of reason' (E IVP37S1). For Spinoza, humans are opposed to one another only insofar as they are governed by passion; when they are governed by reason, their ends align, and the tension between the private interest and the common good is eliminated. Reason teaches that ' $[\mathrm{t}] \mathrm{o}$ man, then, there is nothing more useful than man. Man, I say, can wish for nothing more helpful to the preservation of his being than that ... all, together, should seek for themselves the common advantage all' (E IVP18S). If such genuine change in cupiditates can be achieved, then their singular wills will in fact have the same orientation, and will in fact be unified (Negri 1998: 237). 
Negri's account of pietas thus specifies the conditions under which a democracy can truly be a democracy of the multitude. Negri's Spinozist exegesis is supposed to ground a practical or liberatory politics; ${ }^{4}$ whether it succeeds will depend on how readily these conditions of pietas are achieved. To be sure, Negri's pietas does not appear to demand the ethical virtue of the perfectly rational and free philosopher, but rather a political virtue accessible in principle to everyone: commitment to equality and to the common good (See E IVP37S2). But even so, what ground is there to think that the multitude would ever have this pietas? The contrary view, that multitudes always retain tendencies towards hierarchy and faction, seems just as plausible.

\section{Negri's Spinozist Solution}

Negri's first defence of the multitude's pietas draws on Spinoza's Ethics to argue that individuals in fact come to have pietas, or in other words, to desire the good of their fellow humans, because securing and advancing the wellbeing of fellow humans serves each individual's own virtue and power (potentia). Negri draws attention to passages such as E IVP35C2, in which Spinoza says this reason and virtue arise naturally from the effort of the individual (their striving, or conatus) to preserve themselves and seek their own advantage; and everyone does strive to seek their own advantage. Furthermore, for Spinoza, far from there being a conflict between one's own advantage on the one hand and sociable behaviour on the other, the truly rational individual understands that his or her advantage lies in establishing community with other human beings. ' $[\mathrm{M}]$ en who are governed by reason - that is, men who, from the guidance of reason, seek their own advantage - want nothing for themselves which they do not desire for other men. Hence, they are just, honest, and honorable' (E IVP18S). Sociable behaviour in turn assists the further development of reason in a community, by reducing the frequency and severity of sad passions. Thus, through the process of increasing and mutually reinforcing pietas, pietas begets unity which begets still more pietas, with the result that a unified political subject is produced capable of bearing absolute sovereignty without effacing the singularity of individuals. In other words, the 'tendency toward the collective' is driven by 'the ontologically multiplicative function of pietas and honesty' (Negri 1998: 238; see also Hardt and Negri 2004: 189-90; Negri 2004b: 14). Democracy is 'the limit toward which tend the absoluteness of the mass and the constitutive singularity of potentiae, in other words, the multitudo and pietas' (Negri 1998: 240).

Such an answer taken alone immediately invites scepticism: it is hard to discern a constant tendency towards sociability in the real world. Negri's second defence of the multitude's pietas places an important qualification on his argument: the multitude only in fact increases its power under certain circumstances, namely if it is not hampered by an external force, such as a political 
structure which alienates away its power (1998: 239-40, also 230, 234). ${ }^{5}$ Indeed, Spinoza asserts that a ruler can keep people servile, dividing them amongst themselves and keeping them in fear and away from reason (TP 5.6). But once the alienating structures are removed, in Negri's view the actually existing multitude will have a potentia outweighing its passivity, and it will embark on a virtuous spiral of increase (1998: 237-9). This optimism regarding the multitude's ontological tendency towards virtue is grounded in an asymmetrical view of institutions. Good non-alienating democratic institutions do not need to be externally imposed, for they emanate from the multitude: ' $[\mathrm{t}]$ he institution is thus factually the extrinsic figure of an irrepressible natural process' (Negri 1998: 241, see also 228). It follows that the removal of bad alienating institutions, for instance by revolution, should reveal a multitude of pre-political singularities on a horizontal plain of equality that will not tend to regenerate the bad institutions. Indeed, for this reason Negri equates the power of Spinoza's multitude with the constituent power of social movements against ossified institutions (1991: xxii, 210, 229). ${ }^{6}$

Negri's third defence of the multitude's pietas invokes a progressive view of history. The multitude's tendency towards virtue in specific contexts is undergirded by a larger 'power of the totality of being' that moves through 'constitutive process' towards self-formation and ethicality (Negri 1991: 11213). Specifically, despite temporary setbacks incurred by the hostile force of alienating political structures, in Negri's view the ontological force of the multitude's conatus is so great that it inches towards collective virtue through history. He insists that this collective realisation is not a utopia, but a real material process (1991: 210-29). To be sure, he refuses to hold up a single determinate form towards which the multitude moves. But this does not mean that the movement of the multitude through history lacks direction. Rather, the absence of a determinate ideal of democracy of the multitude corresponds to the fact that the reality of social practice (the concrete nature of the multitude) is always shifting. Although there will have to be juridication formalisations of the multitude's power, these formalisations always need to be ready to be changed (Negri 1998: 240). Negri proposes that in our earthly political predicament, absoluteness might helpfully be conceived as 'the political process in its complexity', or in other words, as the perpetual effort to match the juridical subject of power to social practice (1998: 241).

\section{The Multitude's Power: Spinoza against Negri}

Negri insists that political theory both is and ought to be contested at the level of metaphysics (1991: 43, 211-17; 1998: 220, 225-6, 231; 2004b: 12-13). In this spirit, in this section I examine Negri's account of Spinoza's metaphysics, finding that he gravely misrepresents Spinoza's conatus doctrine, and that he offers an untenable account of the composition of individual powers to form a 
multitude. Once these errors are corrected, a rather different solution to the problem of democracy of the multitude emerges.

Negri attributes to Spinoza a commitment to a directionality in nature, a commitment that fits well with Negri's Marxianism (1991: xx; 1998: 223). However, this attribution is unsustainable. Spinoza's God has no ends, and God is the same as nature: Spinoza denies there is purposive movement in nature (E IP29, IP33, IApp). Negri's error is generated by his conflation of the two senses of potentia (power) (Macherey 1983: 29-30). The first sense denotes an individual's behaviour; what it in fact does. This is the individual's potentia as part of nature, or what is the same, as part of God (TP 2.3). By contrast, the second sense denotes behaviour of an individual that can be understood in terms of the laws its own nature, or in other words, its action (actio) (E IVP4D). This active power proper to an individual is its virtue and freedom. To the extent each thing acts, its behaviour is the product of its own power (potentia), and by this power each thing strives (conatur) to persevere in being (E IIIP6). Yet countless things do not in fact manage to increase or maintain their power; for a thing not only acts, but may also be acted upon (pati), when it behaves in a way which does not accord with the laws of its own nature. To the extent a thing is acted upon, its behaviour is the product of the power and conatus of other things impinging upon it (E IIID2, IIIP4-7, IVD). Indeed, the behaviour of all individuals except God is determined not purely by the individual's own power but also by the power of things around it (E IVP2-4).

As a result, in Spinoza's metaphysics there is no direct practical consequence arising from the identification of a thing's conatus; even if this conatus is characterised as an innate or inherent tendency of the thing, it will only be actualised if the context of other powers around it is conducive. A finite individual strives towards increase of its potentia to the extent it can; but whenever it fails to do so, this simply shows that some other finite individual has succeeded; and Spinoza's God neither privileges one individual's striving over those of any other, nor guarantees that all individuals equally realise their striving. ${ }^{7}$ Consequently, Negri errs in identifying a real directional tendency in nature in general. He also errs in conflating the multitude's freedom and activity with what in fact it tends to do. There are numerous passages in the Ethics which argue that unmediated juxtaposition of human powers in the multitude leads to instability, fear and discord (E IVP40, IVP45C2); and which envisage limits to the powers of the multitude, and its tendency to sad and vicious passions (E IVP54S, IVP58S, IVP70). These passages suggest that, far from there being a virtuous spiral towards pietas, vicious behaviour may lead to an escalation of passion and a dissipation of power. Negri explicitly dismisses these passages as testifying to the 'unfinished character' of E's politics, and then trumps them with passages speaking of the multitude's conatus towards virtue (1998: 237-8). But even if the multitude's potentia qua finite individual includes a striving and a tendency towards pietas, identifying this 
disposition is entirely insufficient to determine the multitude's actual behaviour. Negri often insists upon the elusive or contradictory character of the multitude, but I suspect this elusiveness follows from his own equivocation (1998: 238-9; 2004b: 16).

Spinoza affirms and does not deny the commonsense concern that a community of people may be internally hostile or hierarchical, and that even if the community's power would lie in harmony, there is no necessary tendency in this direction. Spinoza's concern with the dissociative tendencies of the multitude is not limited to the Ethics, but is also to be seen in TP. ${ }^{8}$ Directly after introducing the idea of a horizontal union of human powers, Spinoza dampens the optimism that Negri draws from the idea by observing that hateful passions draw humans apart, and that humans 'are by nature especially subject to these emotions' (TP 2.14). Spinoza insists on the prevalence of vicious behaviour amongst humans: it is quite certain

that men are necessarily subject to passions, and are so constituted that they pity the unfortunate, envy the fortunate, and are more inclined to vengeance than compassion. Furthermore, each man wants others to live according to his way of thinking, approving what he approves and rejecting what he rejects. Consequently, since all men are equally desirous of preeminence, they fall to quarrelling and strive their utmost to best one another; and he who emerges victorious is more elated at having hindered someone else than at having gained advantage for himself. (TP 1.5)

Riven by the passions, humans placed in proximity are just as likely to prey upon one another as to protect one another.

Negri's most plausible line of defence of the practicality of a politics of the multitude's unmediated constituent power is his argument that the multitude's tendency towards virtue will be expressed only if alienating institutions are removed. Correspondingly, Spinoza's pessimistic passages are explained as pertaining to the multitude only under alienating institutions. Nonetheless, this defence also fails, as I will show by considering the sources of weakness within an individual's constitution. Via the conatus doctrine, an individual strives for their power to the extent that they can. Whether an individual is able to act or whether they are passive depends on the relation between their own powers and the powers they confront. Consider an individual human. An individual human's power consists in their physical capacities and their reason and virtue (E IVP21-4). If they are unable to sustain or increase their power, it may be because the external powers they face are very great: for instance, violence and oppression at the hands of other humans. But it can also be that their own power is very weak. Even given physical security, a human individual may not be sufficiently internally well organised and strong to negotiate the world around them on their own rational terms, instead being tossed by each moment's passions. Thus, it is not only gross external forces which prevent individuals from living virtuously and increasing their virtue over time (E IVPref). In the case of the multitude, I argue analogously that the multitude 
can have (indeed, tends to have) internal structural weakness such that no increase of virtue spontaneously arises.

This internal weakness is obscured in Negri's account. Recall the strongly horizontal character of Negri's Spinozist multitude. Negri characterises the multitude as a pure addition of free singularities, and equates these singularities with individuals' potentiae and their freedom (1998: 226, 240). By this term singularity, he means what individuals tend to do, when their power is not politically alienated from them. The situation of non-alienation is positively characterised as 'the liberation of all social energies in a general conatus of the organization of the freedom of all' (Negri 1998: 228). Thus Negri's account relies on conceiving of human singularities as things which can be put in relation yet remain as equals. Their lack of piety simply means it is difficult to get them to agree; achieving piety allows the addition of free singularities to form a unity with one will (Negri 1998: 235, 237). But to the contrary, I argue that Negri's singularities, to the extent they are not already pious, tend to form hierarchies. In consequence, a multitude of Negri's singularities, even when liberated from alienating institutions, itself constantly generates hierarchy internal to itself. Any equality within the multitude is an achievement rather than a starting point, and the means to that achievement are importantly institutional.

On Spinoza's account, individuals tend to enter into hierarchical relations. Friendship is surely the paradigm of a horizontal combination of singular human forces (TP 2.13). But imagine a friendship in which one person is wiser than the other, as surely often occurs. The less wise individual may be reliant on the wiser individual's judgement, and also loyal to that wiser individual as a benefactor. To the extent this occurs, Spinoza concludes the wiser individual has the less wise individual in their power (sub potestate habet) (TP 2.10-11). This innocuous example suggests that unions of human potentiae are likely to feature hierarchy, such that a union's collective power is not equally determined by each individual member. The term potestas is used not merely for juridically alienated authority, but also for concrete and unavoidable hierarchical power in interpersonal relations, even harmless ones. Not all scenarios are so innocuous, and Spinoza suggests several hostile ones: '[o]ne man has another in his power [sub potestate habet] if he holds him in bonds, or has deprived him of the arms and means of self defence or escape, or has terrorised him' (TP 2.10). Here, the hierarchy within the union alienates the singularity of one of the union's members. There may also be a whole range of intermediate scenarios, such as abusive friendship. Spinoza explicitly claims that the only way such relations would not emerge is if the humans concerned were 'altogether free' or entirely guided by reason, for in this case, neither passion nor ignorance nor force subjects them to other people (TP 2.11; E IVP30-5).

As a corollary, the multitude can only spontaneously be an equal combination of free singularities after the perfect rationality of its subjects is achieved. However, even the most virtuous multitude lies a long distance from this philo- 
sophical standard of rationality. A multitude features people of all different ages, and Spinoza insists that everyone is born without reason, and even if they achieve it, it takes the most part of their lives (TTP 16/174). Consequently, 'those who believe that ordinary people ... can be persuaded to live solely at reason's behest are dreaming of the poets' golden age or of a fairytale' (TP 1.5). The practical upshot is that hierarchical relations systematically arise in social interaction; the multitude cannot be conceived as a collection of nonhierarchical singularities. Some of these relations are in accord with reason (for instance, the wise person guiding a less wise friend), but some are not (for instance, a bully terrorising those around them). Negri stresses the natural, pre-political character of Spinozist democratic freedom: the challenge is for it to avoid 'renouncing its own naturalness' (1998: 225). But against this, there is no originary purity to the multitude; the multitude may itself be weak and fail to tend towards virtue even without reference to alienating institutions.

Hierarchical relations between individuals structure the multitude, and some of these relations are alienating. But if we consider political institutions simply as more elaborate types of relations, it follows that even the most alienating institutions that Negri (and Spinoza) are most concerned to critique are part of the actual existence of the multitude. The multitude has political order to correspond to its degree of freedom of power: all different forms of sovereignty are grounded in the potentia of the multitude (TP 2.17). To be sure, the sovereignty is less absolute the more alienated it is. But on my reading, this just shows that the multitude with alienated institutions itself had less power to offer, not that the power was somehow dissipated in the process of its alienation to the sovereign. The existence of good institutions indicates the strength of the multitude, whereas the existence of a very alienating political order, for instance, Hobbesian centralised absolute monarchy testifies to the weakness and lack of virtue of multitude. ${ }^{9}$

This point has sobering implications not only for radical democrats whose faith is vested in a spontaneous constituent power of the multitude, but also for enthusiasts of institutional design, who would seek to remedy all ills by the imposition of good institutions. For a multitude which has lived under alienating institutions will tend to lack virtue and reason and be likely to have a high level of such alienation latent in it. As a consequence, if alienating institutions are simply removed, for instance by revolution, the result will either be war or the resurgence of more bad institutions. It is foolish 'to get rid of a tyrant while yet the causes that have made the prince a tyrant cannot be removed' (TP 5.7). Equally, the imposition of institutions which correspond to a higher degree of virtue is unlikely to succeed. For the foothold of bad institutions is the low degree of potentia of the particular multitude in question (TP 7.26; TTP 18/209-11).

If institutions correspond to a particular state of the power of the multitude, how does change come about? How does a weak multitude with alienated rule increase its power so that it is powerful enough to ward off alienated rule? 
Spinoza's answer is that although institutions will only be effective and durable if they fit with the actual state of the multitude, nonetheless, in moments of clarity people can make incremental modifications to institutions (TP 1, 5.14). And some institutions, whilst fitting to the current state of power of the multitude, nonetheless serve to increase multitude's power.

Institutions need to cleave to some extent to the realities of humans as they exist in their specific degree of powerlessness. Spinoza insists that just because a ruler has the highest right, it does not follow that they have power to make citizens do anything at all (for instance, to make them fly) (TP 4.4). Furthermore, even though it is possible to make quite extreme change in citizens' conduct through coercive means, a good ruler will not do so, instead striving to facilitate the continued activity of citizens in a way that the citizens can recognise as their own (TP 10.8). However, it does not follow from this that non-alienating institutions merely follow the actual contours of the populace, emanating from it without attempting to shape it. Spinoza explicitly rejects granting each the right to live as they please: for this is war and insecurity (TP 3.3). At minimum, for virtue to increase in the multitude, institutions need to constrain the sources of human distress and insecurity (TP 2.21). And beyond this, institutions should not merely limit violence, but substantively shape subjects towards the common good. Because people are not constituted to desire what is most to their advantage,

the state must necessarily be so established that all men, both rulers and ruled, whether they will or no, will do what is in the interests of their common welfare; that is, either voluntarily or constrained by force or necessity, they will all live as reason prescribes (TP 6.3).

Consequently, it is not the pre-political multitude which by itself is non-hierarchical and committed to the common good, and therefore is capable of exercising power. Rather, such a powerful multitude is achieved only through the mediation of well-designed institutions:

But just as the vices of subjects and their excessive licence and wilfulness are to be laid at the door of the commonwealth, so on the other hand their virtue and steadfast obedience to the laws must be attributed chiefly to the virtue and absolute right of the commonwealth (TP 5.3).

That is, the active intervention of institutions is needed to secure equality of condition, to limit self-destructiveness and channel sentiment towards rational (public-spirited) behaviour (TP 1.6, 5.2, 10.9), producing the outward form of virtue (and the space for the possibility of its reality) rather than relying on it as a cause. 


\section{Institutional Implications}

The reader might suspect that the differences identified in the previous sections are insignificant. Negri argues that Spinoza advocates institutions that flatten onto multitude; I by contrast argue that Spinoza advocates institutions that shape the multitude. However, if in both cases we understand Spinoza to be calling for direct democratic institutions, ${ }^{10}$ then we have a theoretical distinction without any practical difference. Against this suspicion, I now show that in fact the theoretical disagreements lead to substantive institutional differences. I argue that for Spinoza the power of the multitude is not necessarily best expressed in thoroughgoing direct democracy. Rather than characterise Spinoza as a direct democrat, it is better to characterise him first of all as an advocate of rule of law, who thinks that popular institutions often, but not always, help secure this rule of law. ${ }^{11}$

Spinoza's final view of the institutional form of a democracy of the multitude cannot be determined directly from his texts, because TP's chapter on democracy was not complete at the time of his death. However, the preceding chapters provide an extremely detailed consideration of the mechanisms of aristocratic and monarchical government, suggesting something similar might apply for democracy. ${ }^{12}$ These constitutions are crafted with view to constraining the conduct of rulers, and effectively mobilising their desires and passions towards the common good (TP 7-10). Nonetheless, Negri rejects any suggestion that the non-mass institutions in Spinoza's aristocracy and monarchy have any corollary or lesson for democracy: the analysis of monarchy and aristocracy features 'a disproportion between the metaphysical role played by the notion of "absolute government" and the guiding idea of the multitudo on the one hand, and the analytical and experimental contents of the constitutional analysis on the other'. He anticipates that the chapter on democracy, had it been completed, would have eliminated this institutional complexity (2004b: 21; see also Matheron 1986: 120-1). Democracy is 'a council composed of the multitude as a whole'; 'democracy as the totality of citizens assembled together' (Negri 2004a: 102, 111; see also 2004b: 19-21). Even though Negri concedes the need for 'functions of control' (1998: 227-8) and even though he thinks that democracy should be animated by tolerance and respect for conscience (1998: 235), he attributes to Spinoza the view that no constitutional limitation is required: the power of the multitude inherently has its own limits, in the sense that oppressive laws will provoke revolt and will thus undermine themselves (2004b: 18). ${ }^{13}$

There is some merit to the view that Spinoza supports mass popular rule. Spinoza claims that democracy has potential to be the most absolute and free political form (TP 11.1); his discussions of aristocracy and monarchy propose that absoluteness can be approached by approximating popular rule (TP 7.31, 8.4). However, Negri's explanation, that such rule reflects the multitude's nature as a collection of free singularities, miscasts Spinoza's reasoning. The 
problem is that rulers are mere humans, prone to forsake the common good for private gain (TP 1.6, 7.27). Forms of popular rule are advocated even in non-popular orders not because the individual singularities that form the multitude are virtuous or because respecting and responding to individual singularity is valued for its own sake. Rather, precisely when individual human singularities are so prone to vice, an institutional structure which secures and relies on the equal standing and influence of a plurality of self-interested individuals can best approximate the common good, and thereby best express and advance the multitude's power.

Furthermore, it is clear that for Spinoza, popular rule is an imperfect and partial solution to the political problem of securing the common good. No states 'have proved so short-lived as popular or democratic states, nor have any been so liable to frequent rebellion' (TP 6.4). Democracies do not maintain themselves; when they are not overcome by rebellion or war, they tend to degenerate into aristocracies and thence monarchies. The reason is "men are by nature enemies, and even when they are joined and bound together by laws they still retain their nature' (TP 8.2). Direct democratic popular rule can harbour pathologies which run counter to the goal of increased unity, virtue and reason: majority tyranny and oppression of minorities, but also partisan and other short-sighted legislation which undermines the constitutional form, subjects' equality, and the multitude's power in the long run. I now turn to consider what other kinds of institutions might be able to address these shortcomings.

Against a view that the best monarchy follows the will of the monarch alone, Spinoza argues that the best monarchy is one which is organised around rule of law: 'it is in no way contrary to practice for laws to be so firmly established that not even the king can repeal them'. The law can hold the political order to reasonable conduct even as the whim and passion of the monarch tends away from it. Spinoza argues this is consistent with the obligation to absolute obedience to the king. 'For the fundamental laws of the state should be regarded as the king's eternal decrees': and ministers should refuse to carry out commands contrary to these fundamental laws. Just as Ulysses was bound to the ship's mast for his own good, so too will a wise monarch subject itself to these laws (TP 7.1). As a corollary, I suggest that for Spinoza obeying the will of the people as it is in fact expressed in a democratic assembly would not be the best way to order a democracy; for the multitude, like the king, can be subject to whims and passions. Instead, a populace ought to consider the law supreme. And just as the law-governed monarchy is still truly a monarchy, so too if people hold the law above the actual will of the people in a democracy, this in no way diminishes the sovereignty of the people.

For Spinoza, the idea of rule of law alone is not enough: 'the main task is to show how it can be brought about that men, whether led by passion or by reason, may still keep their laws firm and sure' (TP 7.2). This task is met in two main ways. First, in carrying out their tasks, state functionaries and min- 
isters must find their private advantage aligned with the general welfare; for people always pursue their own advantage with keenness (TP 7.4). Second, the foundations of the political order need to be set up so that they 'are strong and cannot be dismantled without arousing the indignation of the better part of an armed people' (TP 7.2). This latter point links rule of law to the power of the people, which might seem to favour Negri's direct democratic reading. On this basis, Negri dismisses the institutional details of TP's monarchies and aristocracies as having no relevance for democracy. But this conclusion is premature, as I will show by investigating what concretely it means to ground rule of law in popular power.

The entire patriciate of an aristocracy forms the aristocratic council which is the aristocracy's sovereign (TP 8.1, 8.16). The patriciate does not coincide with the entire political community as the democratic multitude does. Yet the patriciate, considered not in its relation to the commoners but in its relation to itself and conceived as a patrician multitude, faces the very same problem as the democratic multitude. Insofar as its members are not perfectly virtuous, it always risks ruling in a manner that undermines equality amongst patricians and corrupts the aristocratic form. Spinoza's solution is for the patriciate 'to be so bound together by the laws as to form, as it were, a single body directed by a single mind' (TP 8.19). Rule of law coordinates and constrains patricians' actions towards the common advantage.

Spinoza is quite clear that the patriciate cannot rely on itself, as the very same body that makes the law, to uphold and maintain it: the temptation to bend the law for one's friends and associates is too powerful (TP 8.19). A guardian of the laws separate from the patrician council is required: a subcouncil of syndics (TP 8.20). Careful structuring of incentives goes some way to explaining how the syndics can succeed where the patrician assembly would fail. In order not to be dependent on the patriciate which they are supposed to discipline, they are appointed for life; but to prevent them becoming arrogant from long tenure, they are selected from the elder people of the state (TP 8.21). They are paid 'such that they cannot maladminister affairs of state without great loss to themselves' (TP 8.24). Specifically, they keep the fines they collect from patricians who fail to perform their civic duties; and they collect a coin from each householder, allowing them to know the size of the populace (TP 8.25). Such imposed incentives have a greater weight and effect than those which a supreme ruling body might establish for itself. For the structure of these incentives is imposed by the power of the patriciate as a whole; the syndics cannot modify any aspects of these that they find inconvenient. In turn, the patricians will be able to enforce these incentives because the syndics' role is limited: it is relatively simple to see and judge when it is being carried out well, which is not the case when it comes to the broader task of ruling an entire political order.

The effectiveness of the syndics depends on their being grounded in the power of the patriciate, not merely in the sense that the patriciate could support 
them if it chose, but that it will actually be inclined to so do. The syndics will not be able to guard the law if the patriciate ignore their rulings or subvert their institutional structure. Is it unrealistic to expect the patricians to lend support to a body which often thwarts their desires and is insulated from their control? To the contrary, such an expectation does not rely on the patricians having a constant virtuous nature: if they have some minimal recognition of the benefit of no one being able to act with impunity, they will be inclined to support the syndics. For the syndics' sole duty is 'to ensure that the laws of the state regarding assemblies and ministers of state are kept inviolate'; they have the power only 'to bring to judgment any minister guilty of transgressing the regulations pertaining to his office and to condemn him in accordance with established law' (TP 8.20). The narrowness of their role means that it is clear that their power is limited and specific in purpose; so long as they stick to this role, they do not limit any legitimate aspect of the patriciate's rule, nor themselves attempt substantively to rule. Furthermore, within their narrow domain of responsibility they uphold patrician equality. They conduct their business in an internally democratic way, and every patrician has a fair chance one day to be a syndic (TP 8.28, 30).

Thus, the case of aristocracy teaches that even when a political order is constrained to abide by the rule of law by the power of a multitude, for Spinoza this power is not best exercised through a direct democratic procedure. Rather, institutional mediation of that power, by the parcelling out of narrow powers to groups which are insulated from direct democratic decision, is the better path. ${ }^{14}$ Such parcelling is likely to meet success when the domain of its responsibility is narrow, and when it is patently procedurally fair.

This conclusion has implications not only for reconstructing Spinoza's missing chapter on democracy, but also for any attempt to build a present-day theory of democracy on Spinozist foundations. The power of democratic multitude is expressed through a framework of equality and an orientation towards the common good within the strictures of which directly democratic decisions can be made; it is not to be identified with direct democracy itself. Correspondingly, a democracy should renounce its capacity to determine every element of the political order by its direct democratic will. Indeed, even social movements, in order to sustain themselves beyond the initial blush of enthusiasm, create structures of self-limitation (meeting procedures, decision rules, delegation of responsibility); and it is proper that they do so. In the formal sphere of government, the establishment of intermediate and semi-independent bodies need not be seen as a counterweight to the power of the multitude, but rather a potential mode of its expression, insofar as these bodies effectively serve to limit the counterproductive and self-corrupting tendencies of mass democracy. An example is provided by the existence of an independent electoral commission, as is the case in Australia but not in America, which determines electoral boundaries and conducts elections without itself being directly controlled by electoral democracy. 
Spinoza complains that as a result of their idealising approach, philosophers 'have never worked out a political theory that can have practical application' (TP 1.1). The task for radical democrats aspiring to learn from Spinoza is not simply to decry institutional mediation, but instead to discern which particular institutions facilitate the power of the multitude, and encourage it to develop in a more virtuous direction. Even though there is always the risk that non-mass institutions will alienate and thwart the multitude's power, far from there being a relation of opposition between the multitude and such institutions, a serious Spinozist approach to democracy will take an active interest in such forms.

SANDRA Field is a Ph.D. candidate in the Department of Politics at Princeton University. Her research focuses on early modern political philosophy (especially Hobbes and Spinoza), and how it connects with contemporary political theory.

\section{Acknowledgements}

I am grateful for the support of the Princeton University Center for Human Values Political Philosophy Student Research and Travel Fund, endowed by Amy Gutman, the Center's founding director.

\section{Notes}

1. Related conceptions of constituent power are evident in Wolin (1994), Montag (1999: 8089) and Kalyvas (2005).

2. Criticisms of Negri's Spinozism have focussed on its teleology and its periodisation of Spinoza's works, not its account of democracy. See Macherey (1983) and Holland (1998: par. 16-29).

3. Negri (1998: 28-30) claims that Spinoza's theory of the multitude is only fully developed in the late Political Treatise (Spinoza 2000). Correspondingly, I focus primarily on this text. However, I also make use of the Ethics (Spinoza 1994) and the Theological-political Treatise (Spinoza 2001). I rely on Spinoza (1972) for the Latin text.

4. Negri insists that Spinoza presents a realistic theory, not a utopian one (1991: 217-33; 2004b: 9).

5. Elsewhere, Negri characterises the external force differently, as mystification or ideology (Negri 2004b: 22-4).

6. Such a view is not unique to Negri. Despite criticising Negri's account of the entirely preinstitutional multitude, Tully (2008) himself appears committed to an idea of the virtue of political collectivities' immanent informal constitutions, which are only corrupted and made unfree by the imposition of modern (formal juridical) constitutions. 
7. Contrary to Negri's view that 'each rupture of the flow [of the multitude] and every establishment of a rigid form is an act of violence in relation to the tendencies of Spinoza's physics' (1998: 234).

8. See also TTP P/1, 16/174-5.

9. This analysis applies to the alienating political orders which arise within a given society. It does not necessarily apply so well to situations of colonialism and conquest, in which external military force is used to establish the alienating institutions.

10. To be sure, in his own theory of radical democracy, Negri distances itself from direct democracy understood as mere voting, but only because a community must engage together in substantial common activity in order truly to count as democratic. He certainly favours direct popular decision over any institutional delegation of decisions (Hardt and Negri 2000: 373; 2004: xvi, 350-1).

11. See also Smith (2005), Feuer (1958: 136-98), Steinberg (2008), Duff (1903: 365-450). .

12. Spinoza does offer an account of democracy at TTP 16/177-9. However, I agree with Negri that the analysis of politics in TTP is less sophisticated and less defensible that in TP; consequently, I join Negri in attempting to reconstruct the TP view of democracy.

13. It is not clear how Negri reconciles this idea with Spinoza's discussion of Turkish despotism, which is durable despite the pressure it places on its subjects' power (TP 6.4).

14. Balibar also argues that Negri is wrong to say Spinoza rejects the mediation of law and of a hierarchy of councils. However, Balibar does not discuss the distinctive role of smaller institutions (Balibar 1994: 22-3).

\footnotetext{
E: Spinoza 2004

TP: Spinoza 2000

TTP: Spinoza 2001
}

Abbreviations

\section{References}

Balibar, E. 1994. 'Spinoza, the Anti-Orwell: The Fear of the Masses', in Masses, Classes, Ideas: Studies on Politics and Philosophy Before and After Marx, trans. James Swenson. New York: Routledge, 3-37.

Duff, R. A. 1903. Spinoza's Political and Ethical Philosophy. Glasgow: J. Maclehose and Sons.

Feuer, L. S. 1958. Spinoza and the Rise of Liberalism. Boston: Beacon Press.

Hardt, M. and Negri, A. 2000. Empire. Cambridge, MA: Harvard University Press. 
2004. Multitude: War and Democracy in the Age of Empire. New York: Penguin Press.

Hobbes, T. 1994. Leviathan: With Selected Variants from the Latin Edition of 1668. Indianapolis: Hackett.

Holland, E. 1998. 'Spinoza and Marx', Cultural Logic 2(1). http://clogic.eserver.org/2-1/holland.html

Kalyvas, A. 2005. 'Popular Sovereignty, Democracy, and the Constituent Power', Constellations 12(2): 223-44.

Laclau, E. 2004. 'Can Immanence Explain Social Struggles?', in P. A. Passavant and J. Dean (eds), Empire's New Clothes: Reading Hardt and Negri. New York: Routledge, 21-30.

Macherey, P. 1983. 'De la médiation à la constitution: description d'un parcours spéculatif', Cahiers Spinoza 4: 9-38.

Matheron, A. 1986. 'Spinoza et le pouvoir', in Anthropologie et Politique au XVIIe Siècle: Études sur Spinoza. Paris: J. Vrin, 103-22.

Montag, W. 1999. Bodies, Masses, Power: Spinoza and His Contemporaries. London, New York: Verso.

Mouffe, C. 2006. On the Political. London: Routledge.

Negri, A. 1991. The Savage Anomaly: The Power of Spinoza's Metaphysics and Politics, trans. Michael Hardt. Minneapolis: University of Minnesota Press. 1998. 'Reliqua Desiderantur: A Conjecture for a Definition of the Concept of Democracy in the Final Spinoza', trans. Ted Stolze, in W. Montag and T. Stolze (eds), The New Spinoza. Minneapolis: University of Minnesota Press, 219-47. 1999. Insurgencies: Constituent Power and the Modern State, trans. Maurizia Boscagli. Minneapolis: University of Minnesota Press.

2004a. Subversive Spinoza: (Un) contemporary Variations. Manchester, New York: Manchester University Press.

2004b. 'The Political Treatise, or, the Foundation of Modern Democracy', trans. Timothy S. Murphy, in T. S. Murphy (ed.), Subversive Spinoza: (Un) contemporary Variations. Manchester, New York: Manchester University Press, 9-27.

Passavant, P. A. 2004. 'From Empire's Law to the Multitude's Rights: Law, Representation, Revolution', in P. A. Passavant and J. Dean (eds.), Empire's New Clothes: Reading Hardt and Negri. New York: Routledge, 95-120.

Shapiro, K. 2004. 'The Myth of the Multitude', in P. A. Passavant and J. Dean (eds), Empire's New Clothes: Reading Hardt and Negri. New York: Routledge, 289314.

Smith, S. B. 2005. 'What Kind of Democrat was Spinoza', Political Theory 33(1): 627.

Spinoza, B. D. 1972. Spinoza Opera. Heidelberg: Carl Winter.

1994. 'Ethics', trans. Edwin M. Curley, in A Spinoza Reader: The Ethics and Other Works. Princeton: Princeton University Press, 85-265. Cited as E, followed by Curley's referencing convention.

2000. Political Treatise, trans. Samuel Shirley. Indianapolis: Hackett. Cited as TP, followed by chapter and paragraph number.

2001. Theological-political Treatise, trans. Samuel Shirley. Indianapolis:

Hackett. Cited as TTP, followed by chapter number and Hackett pagination. 
Steinberg, J. D. 2008. 'Spinoza on Being Sui Juris and the Republican Conception of Liberty', History of European Ideas 34: 239-49.

Tully, J. 2008. 'Modern Constitutional Democracy and Imperialism', Osgoode Hall Law Journal 46: 461-93.

Wolin, S. S. 1994. 'Fugitive Democracy', Constellations 1(1): 11-25.

Žižek, S. 2005. 'Objet $a$ as Inherent Limit to Capitalism: On Michael Hardt and Antonio Negri'. Available at http://www.lacan.com/zizmultitude.htm (accessed 11 December 2011). 